6. Ivanov, V. (2007). Dictionary of wind player. Moscow: Muzyka [in Russian].

7. Platonov, N. (1958). Questions on the methodology of teaching wind instruments. Moscow: Muzgiz [in Russian].

8. Pushkarev, V. (2000). The aperture of the language - the formation and development when playing the pipe. Moscow: MGK im. P. I. Chakovskogo [in Russian].

9. Pushkarev, V. (2013). Trumpet playing technique. [online] YouTube. Available at: https://www.youtube.com/watch? $\mathrm{v}=$ nh0aTzCZ428\&fbclid=IwAR39HLNZL1 [Accessed 03 February 2019] [in Russian].

10. Rozanov, S. (1935). Fundamentals of teaching to play brass instruments. Moscow: Muzyka [in Russian].

11. Usov, A. (1965). Questions of the theory and practice of playing the horn. Moscow: Muzyka [in Russian].

12. Usov, A. (1971) Ways to improve the performance technique of horn player. Metodika obuchenija igre na duhovyh instrumentah, 3, pp. 248-266 [in Russian].

13. Usov, J. (1989). Portraits of Soviet performers on wind instruments. Moscow [in Russian].

14. Farkas, F. (1998). The art of playing brass instruments. V. Serikova (Trans.). M. Derugin (Ed.). Moscow: MGK imeni P. I. Chajkovskogo [in Russian].

15. Cypin, G. (1999). Artist and technology. Moscow: Akademija [in Russian].

16. Yakustidi, I. (1977). Methods of teaching to play the horn. Kyiv: Muzychna Ukraiina [in Ukrainian].

УДК 37.018.54:784 Киї “19”

DOI: https://doi.org/10.33643/kmus.2019.58.18

олеся Небога,

аспірантка кафедри мистеитвознавства Київського національного університету культури та мистеитв, викладач кафедри естрадного співу Київської мунічипальної академії музики імені Р. М. Глієра https://orcid.org/0000-0001-8731-4130 olesya.neboga@rambler.ru

Olesia Neboha, Postgraduate at the Department of Study of Art, Kyiv National University of Culture and Arts, Lecturer at the Department of Pop Vocal Performance, R. Glier Kyiv Municipal Academy of Music https://orcid.org/0000-0001-8731-4130 olesya.neboga@rambler.ru

\title{
ВТІЛЕННЯ ТВОРЧИХ ПРИНЦИПІВ КИЇВСЬКОЇ ВОКАЛЬНОЇ ШКОЛИ У ВИКОНАВСЬКОМУ МИСТЕЦТВІ СПІВАКІВ СВІТОВОГО РІВНЯ
}

Проаналізовано процес становлення київської вокальної школи, підкреслено важливу роль у цьому процесі педагогів О. Мишуги та 
О. Муравйової, а також їхніх учнів і послідовників - Д. Свтушенко, М. Донець-Тессейр та інших. З'ясовано декілька основних творчих принципів представників київської вокальної школи. Виокремлено трьох видатних українських співаків другої половини XX ст. - М. Кондратюка, Є. Мірошниченко та А. Кочергу, на прикладі виконавської діяльності яких показано практичне втілення цих творчих принципів. Автором підкреслено, що під терміном «вокальна школа» розуміється система мистецьких принципів та прийомів, спільних для провідних педагогів київських учбових закладів та їхніх видатних випускників.

Ключові слова: вокальна школа, мистецтво, спів, голос, принципи, педагогіка.

Neboha Olesia. The implementation of creative principles of Kyiv vocal school in the performing art of world class singers. The relevance of the study is determined by the lack of research on the main creative grounds of the Kyiv vocal school as the unified artistic platform. The main objective of the study is to reveal the art principles of the school and to investigate their embodiment in the performing art of outstanding Ukrainian singers.

The methodology. A historicism was applied in investigation on evolutionary process of the school formation. In addition, general scientific methods (structural, systemic) were used in describing existing concepts of schools' scientific comprehension and the method of each teacher, and comparative methods - in order to correlate them.

In essence, the scientific novelty is that the Kyiv vocal school is being studied as an integral system with a number of distinctive features and common creative principles for all of its representatives.

The process of the formation of the Kyiv vocal school is analyzed in the article emphasizing the important role of the teachers O. Mishuga and O. Muraveva, as well as their students and followers - D. Yevtushenko, M. Donets-Tesseir and others. There are singled out three distinguished Ukrainian singers of the second half of the XXth century - M. Kondratyuk, E. Miroshnichenko and A. Kocherga. The practical embodiment of these creative principles is reflected on their activities example. The author emphasizes that the term «vocal school» is understood as a system of artistic principles and techniques common to leading teachers of educational institutions and their outstanding graduates. The study result is highlighting several common creative principles, the characteristics of the prominent Kyiv vocal school representatives.

Key words: vocal school, art, singing, voice, principles, pedagogy. 
Небога Олеся. Воплощение творческих принципов киевской вокальной школы в исполнительском искусстве певцов мирового уровня. В статье проанализирован процесс становления киевской вокальной школы, подчеркнуто важную роль в этом процессе педагогов А. Мишуги и Е. Муравьевой, а также их учеников и последователей Д. Евтушенко, М. Донец-Тессейр и других. Актуальность выбранной проблематики обусловлена отсутствием исследования, посвященного выявлению основных творческих принципов киевской вокальной школы как единой художественной платформы. Цель статьи - проследить воплощение основных принципов названной школы в исполнительском искусстве выдающихся отечественных певцов второй половины XX вв.Н. Кондратюка, Е. Мирошниченко и А. Кочерги. В процессе работы над статьей были применены такие методы исследования, как метод историзма, а также структурный и системный методы. Научная новизна заключается в том, что киевская вокальная школа исследуется как целостная система с рядом характерных признаков и общих для всех ее представителей творческих принципов. Автором подчеркивается, что под термином «вокальная школа» понимается система художественных приемов, общих для ведущих педагогов киевских учебных заведений и их знаменитых выпускников-исполнителей. И хотя киевская школа по сравнению с другими европейскими выглядит относительно молодой чуть более чем за сто лет она прошла период становления, формирования основных методических положений, активного развития и сейчас проходит этап искусствоведческого осмысления и обобщения. В результате исследования было предложено пять основных творческих принципов, которые были успешно воплощены в жизнь разносторонней деятельностью всемирно известных певцов и педагогов. При этом важной особенностью киевской школы сольного пения является ее самобытность, разнообразие педагогических и научных подходов, что делает ее знаковым явлением на территории мирового вокального исполнительства.

Ключевые слова: вокальная школа, искусство, пение, голос, принципы, педагогика.

Постановка проблеми. Київська вокальна школа, порівняно 3 іншими європейськими, виглядає відносно молодою - їй трохи більше, ніж сто років. За цей час вона пройшла період становлення, формування основних методичних положень, пріоритет яких залежав від індивідуального методу викладача, період бурхливого розвитку й, нарешті, сьогодні проходить етап мистецтвознавчого осмислення та узагальнення. 
Етимологічно слово «школа» походить від грецького слова бұоди́ («сколе»), що означає «дозвілля» або проведення вільного від роботи часу. У Стародавній Греції філософи та їхні учні збиралися разом і обговорювали різні питання, вели глибокі, повчальні бесіди. 3 часом у цих мудреців $\mathrm{i}$ мислителів з'явилися постійні учні, і поняття «школа» стало означати навчальний процес, а пізніше й приміщення, для нього пристосоване.

У сучасному мовленнєвому вжитку «школа» має декілька смислових відтінків - як навчально-виховний заклад, як набуття досвіду, вишкіл, система освіти та як науковий, літературно-художній чи політичний напрямок, що характеризується певними відмінними ознаками.

У контексті теми статті під терміном «вокальна школа» розуміється система мистецьких принципів і прийомів, спільних для провідних педагогів київських навчальних закладів та їхніх видатних випускників. 3 цієї точки зору видається актуальним дослідити основні творчі принципи представників київської вокальної школи на прикладі конкретних персоналій.

Аналіз останніх досліджень та публікацій. У період існування незалежної України київська школа академічного сольного співу неодноразово була об'єктом наукової уваги, як у педагогічному, так і в мистецтвознавчому аспектах. До найважливіших педагогіко-методичних праць віднесемо підручник В. Антонюк «Вокальна педагогіка: сольний спів», що має вже три видання (Київ, 2007, 2012, 2017), монографію В. Вотріної «Мистецтво співу і вокальна методика М. Е. Донець-Тессейр» (Київ, 2001), численні статті Ю. Грищенко, як то «Розвиток професійної вокальної освіти в Києві (кінець ХІХ - початок ХХ ст.)» (Ніжин, 1999), «Провідні тенденції професійної вокальної підготовки в контексті завдань сучасної мистецької освіти» (Бердянськ, 2010) та інші. Окремі дослідження присвячено провідним педагогам київських навчальних закладів, зокрема, це кандидатська дисертація Н. Ващенко «Творча спадщина Олександра Мишуги (1852-1922рр.) в контексті розвитку української мистецької педагогіки» (Полтава, 2015), роботи Т. Давлатової «Творчий шлях Марії Донець-Тессейр (за архівними матеріалами)» (Київ, 2018) та «Виконавська школа Марії Едуардівни Донець-Тессейр у вимірах українського вокального мистецтва» (Київ, 2018), стаття Г. Швидків «Ретроспективний аналіз становлення вокальної педагогіки в Україні на прикладі київської вокальної школи» (Київ, 2013). Дослідник Б. П. Гнидь створив окремий нарис про педагогів кафедри сольного співу Національної музичної академії - «Виконавські школи України: Кафедра сольного співу НМАУ ім. П. І. Чайковського (1971-2001)» (Київ, 2002). 
У більш широкому мистецтвознавчому аспекті вітчизняна вокальна школа досліджується в роботах Б. Гнидя «Історія вокального мистецтва» (Київ, 1997) та «Українська вокальна школа в контексті світового виконавського мистецтва» (Київ, 1999), В. Антонюк «Українська вокальна школа: на перехресті етнокультурних доріг» (Київ, 2001), «Етнокультурологічний тезаурус українського вокального мистецтва» (Київ, 2002), «Етномузикологічні тенденції української вокальної школи» (Київ, 2008), у монографії О. Шуляр «Історія вокального мистецтва» (Івано-Франківськ, 2013).

Методи дослідження. У процесі роботи над статтею було застосовано метод історизму - для вибудовування еволюційного процесу становлення школи. Окрім цього використано загальнонаукові методи, зокрема структурний i системний - при описі існуючих концепцій наукового осмислення школи та методу кожного з викладачів, - а також компаративний - 3 метою їх співвідношення.

Мета статті - виявити основні творчі засади київської вокальної школи й дослідити їхнє втілення у виконавському мистецтві видатних вітчизняних співаків.

Наукова новизна полягає в тому, що київська вокальна школа досліджується як цілісна система з низкою характерних ознак і спільних для всіх їі представників творчих принципів.

Виклад основного матеріалу. Формування київської вокальної школи, в розумінні єдиної мистецької платформи, неможливо уявити без існування серйозного педагогічного осередку, яким став перший у Києві спеціалізований мистецький навчальний заклад - музичне училище (нині Київська муніципальна академія музики ім. Р. М. Глієра), заснований 1868 року. Ця освітня інституція (початкова назва - музична школа, згодом училище) з першого року своєї діяльності проводила підготовку учнів на п'яти відділах: фортепіано, скрипка, віолончель, теорія музики та спів. Крім того, в училищі існував хоровий клас, а з 1885 року - клас оперного співу.

Бурхливого розвитку київська вокальна школа набула в першій половині ХХ століття, коли в заснованій 1913 року Київській консерваторії відкривається кафедра сольного співу. Плідна творча діяльність видатних педагогів і артистів-співаків - О. Мишуги, О. Гродзинського, О. Муравйової, Д. Свтушенка, М. Донець-Тессейр, Є. Мірошниченко, І. Паторжинського та інших - дозволяє назвати їх фундаторами національної школи співу.

Особливо цінною в цьому процесі видається роль видатного співака й педагога, професора Олександра Мишуги (1853-1922), який відгукнувся на запрошення Миколи Лисенка та приїхав до Києва викладати в Музично- 
драматичній школі. Він виховав цілу плеяду талановитих артистів i вокальних педагогів, зокрема майбутніх професорів Київської консерваторії Марію Донець-Тессейр та Михайла Микиша. Надзвичайно важливим $є$ те, що основоположник київської вокальної школи Олександр Мишуга велику увагу приділяв теоретичним аспектам: анатомофізіологічній будові голосового апарату, проблемам акустики та інтерпретації музичних творів. Це був перший український митець, який «намагався поставити вокальну педагогіку на наукову основу, вивести іiї із сфери емпіричності та “секретності”» [4, с. 259].

Роботу над музичним твором педагог починав 3 вербального тексту, бо вважав, що «спів $є$ також мова, тільки 3 подовженими складами й у відповідних музично-вокальних звуках. $<\ldots>$ Для доброго співу потрібно спочатку навчитися правильно і виразно говорити; щоб слова вокального тексту були виразними i зрозумілими, як i при звичайній розмові» (цит. за [3, с. 10]).

Справу викладача продовжили його учні. Як справедливо зазначила С. Царук, «педагогічна діяльність декількох поколінь послідовників вчення Мишуги не обмежувалась безпосередньо підготовкою співаків, але i зробила значний внесок у розвиток теорії вокального мистецтва. Продовження справи великого учителя здійснювалося з однією метою втілення в життя мрії О. Мишуги, який понад усе бажав для України створення єдиної вокальної школи, яка базувалась би на науково обгрунтованих принципах вокальної методології» [6, с. 128].

Близько п'ятисот співаків, серед яких народні й заслужені артисти України, виховала протягом насиченого творчого шляху професор, заслужений діяч мистецтв Олена Муравйова (1867-1939). Вона розробила яскраву авторську методику, яка стала основою для подальшого розвитку вітчизняної вокально-педагогічної системи. Ї̈̈ найвідоміші учні- це Дометій Євтушенко, Зоя Гайдай, Римма Разумова, Лариса Руденко, Іван Козловський та багато інших. Однією 3 найважливіших вимог О. Муравйової-викладача було досягнення бездоганної технічної майстерності для досконалого художнього виконання музичного твору.

Важливими постатями у формуванні основоположних принципів української вокальної школи були заслужені діячі мистецтв України, професори Дометій Свтушенко (1893-1983) та Марія Донець-Тессейр (1889-1974). Обидва славетних педагоги були одночасно популярними практикуючими співаками, виконуючи провідні ролі у відомих оперних творах. Своїми численними науковими працями з теорії викладання співу вони значно розвинули існуючі на той час вокально-педагогічні методики. 
Базовою життєвою установкою М. Донець-Тессейр, як і її вчителя О. Мишуги, було невпинне самовдосконалення, постійне професійне зростання. Вона була глибоко переконана, що тільки ті митці, які готові на вівтар мистецтва покласти все своє життя, досягнуть успіху. Саме наполегливість i вимогливість дослідниця В. Вотріна вважає визначальними в характері М. Донець-Тессейр: «Велике захоплення, жагуча закоханість не тільки в мету, але й у працю, що веде до цієї мети, одна з яскравих ознак таланту. Тільки така пристрасть, яка переходить у зосереджену працю, у вправи, розлючена холоднокровність яких живиться високим жаром невмираючого "хочу" - тільки така пристрасть має ціну в мистецтві, тільки вона народжує уміння» [3, с. 30].

Однією з визначних постатей серед фундаторів вітчизняної вокальної школи був, безсумнівно, самобутній педагог Олександр Гродзинський (1891-1973), який виховав, зокрема, славетного оперного співака, майбутнього ректора Київської консерваторії Миколу Кондратюка. Викладацьку методику О. Гродзинського було засновано на симбіозі співочої манери російської та італійської вокальних шкіл, а такожукраїнського народного співу ліричних пісень.

Численні вихованці зазначених вище співаків-педагогів продовжили розвивати творчі ідеї своїх славетних вчителів, уже власною виконавською та педагогічною діяльністю примножуючи здобутки київської вокальної школи. Серед них виділимо співаків світового рівня, активна діяльність яких припадає на другу половину XX століття - М. Кондратюка, Є. Мірошниченко та А. Кочергу.

Учень О. Гродзинського (із сольного співу) та 3. Ліхтман (3 камерного співу) Микола Кондратюк (1931-2006) володів рідкісним за силою та широтою діапазону баритоном, а також надзвичайною виконавською харизмою. Унікальності тембру його голосу додавало самобутнє «українське забарвлення». Митець «мав виняткову здатність відчути й передати особливий, часом невловимий в академічному виконанні національний колорит, що містить у собі психоемоційну ауру етносу». [1, с. 100]. Адже фундаментом мистецтва М. Кондратюка завжди були національні фольклорні джерела, що тим чи іншим чином проявлялося в його виконанні - це і рідкісна поетичність, емоційна щирість, простота й піднесеність кожного виступу.

Життя було не надто лагідним до видатного митця. Від самого дитинства він був змушений багаторазово переїжджати. Народився Микола Кіндратович у Хмельницькій області, дитинство провів у Полтаві, далі була евакуація на Урал, а після повернення на батьківщину - навчання у 
Київській консерваторії та стажування в Міланському La Scala. Коли співак приїхав до Італії навчитися знаменитому мистецтву belcanto, на нього чекала приємна новина - він дізнався, що вже володіє всіма необхідними знаннями. Це й не дивно, адже вчитель М. Кондратюка О. Гродзинський мав за плечима італійську школу: свого часу він навчався у Етторе Гандольфі, коли того запросили викладати в Київській консерваторії.

М. Кондратюк працював солістом Державного народного хору ім. Г. Верьовки, Київського академічного театру опери та балету ім. Т. Шевченка, протягом трьох років - солістом Большого театру в Москві. Підкоривши оперні сцени, співак несподівано обирає кар'єру камерного концертного виконавця i в цій сфері отримує найвище визнання-звання народного артиста України. 3 1970-х років митець зосереджує свою увагу на педагогічній діяльності у столичній консерваторії, упродовж 1974-1983 років - іiі ректор, з 1979 - професор. Викладацьку діяльність М. Кондратюк успішно поєднував із концертною увійшли в історію його численні тріумфальні виступи в Україні, Росії, країнах Європи та Америки. У різноманітному творчому доробку співака біля п'ятисот камерних творів, а також низка провідних ролей в оперних шедеврах вітчизняних і зарубіжних композиторів.

Пройшовши грунтовну вокальну підготовку в класі професора Київської консерваторії Марії Едуардівни Донець-Тессейр та стажування в театрі La Scala, на світову оперну сцену виходить ще одна славетна українська співачка - Євгенія Мірошниченко (1931-2009). Як влучно зазначила Т. Швачко, автор єдиної на сьогодні монографії, присвяченої постаті видатної виконавиці, «вона була окрасою і символом української опери другої половини XX століття, з ії мистецтвом пов'язана світова слава національної вокальної школи» [7, с. 28]. I дійсно, світлий, ніжний та водночас сильний голос співачки (колоратурне сопрано), іiі проникливе та експресивне виконання, досконале володіння технічними віртуозними прийомами - все це не лишало байдужим слухачів. Є. Мірошниченко володіла унікальним діапазоном, що досягав таких нот, як «ля» третьої і навіть «до» четвертої октав.

Крім оперної та концертної виконавської діяльності, $€$. Мірошниченко проводила активну педагогічну роботу, створивши власну вокальну школу. Упродовж тридцяти років викладання в Національній музичній академії України ім. П. І. Чайковського $Є$. Мірошниченко докладала великих зусиль для того, щоб не тільки навчити своїх студентів співу, але й передусім, надихнути їх на постійне самовдосконалення. 
Педагогічна методика Свгенії Семенівни базувалася на природному поєднанні традицій українського та італійського виконавства.

Нездійсненою мрією співачки лишилося відкриття Малої опери в Києві. Цьому проекту вона віддала багато душевних сил, мріючи про концертний майданчик, на якому могли б ставитися експериментальні й маловідомі твори та отримували б необхідну концертну практику молоді таланти. I хоча 2005 року на папері було відкрито цей заклад культури, через невирішені питання з земельною ділянкою, на якій знаходиться будівля, Мала опера й досі не функціонує.

Різнобічна обдарованість та активність у мистецькому й громадському житті суспільства, характерні для провідних представників київської вокальної школи, властиві і Євгенії Мірошниченко. Дійсно, усі «ті, хто знали “українського соловейка" особисто, впевнені, що ії творча індивідуальність далека від загального стереотипу оперної примадонни (до того ж, колоратурного сопрано) із притаманними йому штучністю, самозакоханістю, завищеною самооцінкою та вузьким колом інтересів. Свгенія Семенівна була природною у будь-яких проявах, людиною чесною, освіченою, і певною мірою жертовною, яка дбала не лише про власний комфорт, але й про гідний внесок у загальнолюдську мистецьку скарбницю» [5, с. 18].

$€$. Мірошниченко вважається не тільки неперевершеною виконавицею барокових творів, а й завзятою прихильницею української музики - значну частину її репертуару складали обробки народних пісень та солоспіви українських композиторів.

Слід також відзначити особливе акторське обдарування співачки, про що влучно зауважує дослідниця В. Антонюк: «Рідкісний природний акторський хист Євгенії Мірошниченко за силою сценічної виразності не поступився феномену іï лірико-колоратурного сопрано, що дозволяє дослідникам творчості української оперної примадонни віднести втілені українською мисткинею художні образи оперних героїнь до рівня світових еталонів сценічної майстерності» [1, с. 99]. Цю рису підкреслює i ii колега, видатний співак І. Козловський: «Наша Женя не тільки співачка від Бога, а ще й справжня актриса від Бога. Таке поєднання зустрічається дуже рідко» (цит. за [7, с. 30]). Найбільш вдавалися їй суперечливі, драматичні, трагічні образи. Улюбленим оперним образом Є. Мірошниченко була Віолетта 3 опери Дж. Верді «Травіата», трагічна доля якої знайшла своє блискуче втілення в інтерпретації актриси. Цією оперою розпочався творчий шлях мисткині, про що вона сама розповідала: «Своє народження як співачки пов'язую насамперед із “Травіатою" - цим шедевром Джузеппе Верді. Саме в ній відбулося моє 
артистичне становлення. А трагічна й чарівна Віолетта - моя незрадлива й щира любов»${ }^{1}$ Ц Цією ж партією 1994 року видатна співачка завершила свою діяльність на оперній сцені, зосередившись на викладацькій та суспільно-громадській роботі.

Успішним представником київської вокальної школи $\epsilon$ також Анатолій Кочерга (нар. 1947) - випускник класу Р. Разумової (учениці славетної О. Муравйової). Так само, як і його старші видатні сучасники М. Кондратюк та $Є$. Мірошниченко, після навчання в консерваторії він проходить стажування в театрі La Scala i досягає високого рівня вокально-технічної та акторської майстерності. Процес професійного зростання потребує докладання значних зусиль. Дослідник вітчизняного оперного мистецтва В. Бондарчук, стверджує, що «динаміка накопичення потенційного досвіду, в площині складної структурної сітки мистецького середовища, обумовлює дотримання раціональної послідовності в опануванні виконавських механізмів як акторської майстерності, так і вокально-сценічного професіоналізму» [1].

Унікальність голосу А. Кочерги (бас) - у його неймовірній силі, яскравому тембрі та надзвичайно широкому діапазоні. Світову славу приніс співакові образ Бориса Годунова в однойменній опері М. Мусоргського, втілений з високим рівнем драматизму (цю партію актор виконав понад 500 разів на різних оперних сценах світу!).

А. Кочерга співпрацює з відомими диригентами, активно виступає на сценах Європи, лишаючись при цьому громадянином України. «...мені постійно пропонують залишатися за кордоном. А я не хочу. Я їжджу на роботу... На всіх афішах, практично всіма мовами світу написано, що я - 3 України. I я пишаюся цим», - зізнається співак ${ }^{2}$. Своїм основним завданням А. Кочерга вважає піднесення та популяризацію українського мистецтва, як композиторського, так і виконавського.

Підсумовуючи наведені вище творчі характеристики видатних представників київської вокальної школи, виділимо декілька спільних принципів, серед яких наступні:

- досягнення вокально-технічної досконалості задля якнайкращого розкриття художньому задуму;

- невпинний саморозвиток, професійне зростання;

\footnotetext{
1 З інтерв’ю для журналу «Музика». 1994. № 2. С. 134.

${ }^{2}$ Співак Анатолій Кочерга: «Може, варто було б змінити гімн України?» // Дзеркало тижня : міжнародний громадсько-політичний тижневик. Випуск № 8. 26 лютого 5 березня 2010 року. URL: https://dt.ua/SOCIETY/spivak_anatoliy_kocherga_mozhe, varto_bulo_b_zminiti_gimn_ukrayini.html_(дата звернення: 21.05.2019).
} 
- у вокальній методиці - органічне поєднання традицій світових шкіл 3 етнічною самобутністю українського співу;

- популяризація вітчизняного мистецтва;

- успішне співвідношення концертної, педагогічної та суспільної діяльності.

Висновки. Київська вокальна школа, що сформувалася та активно розвивалася протягом XX ст., набула тих характерних ознак і спільних для усіх іiі представників творчих принципів, що дозволяють визначити іiі як єдину мистецьку платформу. При цьому важливою рисою $є$ iii самобутність, різноманіття педагогічних підходів, що робить ііі знаковим явищем на теренах світового вокального виконавства.

Значний внесок у формування професійного вокального мистецтва України зробили видатні артисти та педагоги - О. Мишуга, О. Муравйова, М. Донець-Тесейр, О. Гродзинський, які дали імпульс для його подальшого розвитку. Їхні славетні випускники, зокрема М. Кондратюк, Є. Мірошниченко та А. Кочерга, доклали великих зусиль для розповсюдження вітчизняного мистецтва на увесь світ. Своєю невтомною різнобічною діяльністю ці всесвітньовідомі співаки та педагоги переконливо продемонстрували практичне втілення основних принципів київської вокальної школи, яскравими представниками якої вони $\epsilon$.

1. Антонюк В. Г. Вокальна педагогіка : сольний спів. Вид. 3-те, доп. і перероб. Київ : Видавець Бихун В. Ю., 2017. 218 с.

2. Бондарчук В. Д. М. Гнатюк i вітчизняне оперне виконавство (становлення особистості) // Київське музикознавство : зб. наук. ст. Вип. 57. Київ, 2018. С. 201211. URL: https://kyivmusicology.com/index.php/journal/article/view/25/24 (дата звернення: 15.05.2019).

3. Вотріна В. В. Мистецтво співу i вокальна методика М. Е. Донець-Тессейр : монографія. Київ, 2001. 273 с.

4. Гнидь Б. П. Історія вокального мистецтва : підручник. Київ : НМАУ ім. П. І. Чайковського, 1997. 320 с.

5. Касьяненко М. Життя та творчість Євгенії Мірошниченко: джерелознавчий аспект : дис. ... канд. мистецтвознавства : 17.00 .03 / Харків. нац. ун-т мистецтв ім. І. П. Котляревського. Харків, 2018. 249 с.

6. Царук С. Втілення педагогічних засад Олександра Мишуги у діяльності М. Е. Донець-Тессейр // Наукові збірки Львівської національної музичної академії ім. М. В. Лисенка. Вип. 37 : Етномузикологія. Львів, 2015. С. 125-142.

7. Швачко Т. Співачка й актриса від Бога // Музика. 2011. № 3. С. $28-33$.

\section{References}

1. Antonyuk, V. (2017). Vocal pedagogy: solo singing. Kyiv: Publisher Bykhun V. U. [in Ukrainian]. 
2. Bondarchuk, V. (2018). M. Gnatyuk and native opera performance (formation of personality). Kyivske muzykoznavstvo, [online] 57, pp. 201-211. Available at: https://kyivmusicology.com/index.php/journal/article/view/25/24 [Accessed 15 May 2019] [in Ukrainian].

3. Votrina, V. (2001). Art of singing and vocal technique of M. Donets-Tesseir. Kyiv [in Ukrainian].

4. Hnyd, B. (1997). History of vocal art. Kyiv: NMAU im. P. I. Chaykovskogo [in Ukrainian].

5. Kasyanenko, M. (2018). Life and creativity of Eugenia Miroshnichenko: source-study aspect. $\mathrm{PhD}$ thesis. Kharkiv National I. P. Kotlyarevsky University of Arts. Kharkiv [in Ukrainian].

6. Tsaruk, S. (2015). Implementation of the pedagogical principles of Alexander Mishuga in the work of M. Donets-Tesseir. Naukovi zbirky Lvivskoi natsionalnoi muzychnoi akademii im. M. V. Lysenka, 37, pp. 125-142 [in Ukrainian].

7. Shvachko, T. (2011). Singer and actress from God. Muzyka, 3, pp. 28-33 [in Ukrainian].

УДК 398.8(=161.2)

DOI: https://doi.org/10.33643/kmus.2019.58.19

\author{
Олена Серко, \\ аспірант кафедри музичної фольклористики \\ Львівської національної музичної академії ім. М. В. Лисенка, \\ викладач Рівненського музичного училища РДГУ \\ https://orcid.org/0000-0003-4361-2640 \\ len922@ukr.net \\ Olena Serko, \\ Postgraduate at the Department of Musical Folklore, \\ Lviv National Musical Academy named after Mykola Lysenko, \\ lecturer at Rivne Musical College \\ https://orcid.org/0000-0003-4361-2640 \\ len922@ukr.net
}

\title{
ЗБИРАЦЬКА СПАДЩИНА СТЕПАНА ТУРИКА
}

Публікацію присвячено дослідженню рукописів народних пісень, зібраних Степаном Туриком протягом 1912-1978 років. Актуальність обраної теми зумовлена тим, що в статті вивчаються невідомі архівні матеріали, що презентують народномузичний репертуар досі малодосліджених територій станом на середину XX століття. У запропонованій роботі вперше здійснено аналіз збирацької спадщини С. Турика.

Усю інформацію, що міститься в рукописах нотних зошитів, спочатку було систематизовано в таблиці Excel та проаналізовано. Це дало можливість зібрати певні відомості про збирацьку діяльність (дата, місце запису) та спадщину (жанри та коментарі до народних пісень) С. Турика, дані про інформантів, а також конкретизувати деякі факти з біографії дослідника. Додатки, вміщені в статті, значно доповнюють викладену інформацію. 